\title{
The Ion Channel TRPA1 Is Required for Chronic Itch
}

\author{
Sarah R. Wilson, ${ }^{1,2}$ Aislyn M. Nelson, ${ }^{3,4}$ Lyn Batia, ${ }^{1}$ Takeshi Morita, ${ }^{1,2}$ Daniel Estandian, ${ }^{1,2}$ David M. Owens, ${ }^{3,5}$ \\ Ellen A. Lumpkin, ${ }^{3,6}$ and Diana M. Bautista ${ }^{1,2}$ \\ ${ }^{1}$ Department of Molecular and Cell Biology and ${ }^{2}$ Helen Wills Neuroscience Institute, University of California, Berkeley, California 94720-3200, ${ }^{3}$ Department \\ of Dermatology, Columbia University, College of Physicians and Surgeons, New York, New York 10032, ${ }^{4}$ Medical Scientist Training Program, Baylor College \\ of Medicine, Houston, Texas 77030, ${ }^{5}$ Department of Pathology and Cell Biology and ${ }^{6}$ Department of Physiology and Cellular Biophysics, Columbia \\ University College of Physicians and Surgeons, New York, New York 10032
}

Chronic itch is a debilitating condition that affects one in 10 people. Little is known about the molecules that mediate chronic itch in primary sensory neurons and skin. We demonstrate that the ion channel TRPA1 is required for chronic itch. Using a mouse model of chronic itch, we show that scratching evoked by impaired skin barrier is abolished in TRPA1-deficient animals. This model recapitulates many of the pathophysiological hallmarks of chronic itch that are observed in prevalent human diseases such as atopic dermatitis and psoriasis, including robust scratching, extensive epidermal hyperplasia, and dramatic changes in gene expression in sensory neurons and skin. Remarkably, TRPA1 is required for both transduction of chronic itch signals to the CNS and for the dramatic skin changes triggered by dry-skin-evoked itch and scratching. These data suggest that TRPA1 regulates both itch transduction and pathophysiological changes in the skin that promote chronic itch.

\section{Introduction}

Chronic itch is a widespread and debilitating condition that results from a variety of pathological conditions such as eczema, kidney failure, cirrhosis, nervous system disorders, and some cancers (Bowcock and Cookson, 2004; Yosipovitch, 2004; Ikoma et al., 2006). Although a number of factors have been identified that mediate acute itch transduction in primary sensory afferents and the CNS, several major obstacles persist that cloud our understanding of chronic itch (Dong et al., 2001; Sun and Chen, 2007; Liu et al., 2009; Sun et al., 2009; Lagerström et al., 2010; Ross et al., 2010; Wilson et al., 2011; Liu et al., 2011; Han et al., 2013). First, very little is known about the fundamental basis for chronic itch perception, including the molecules that underlie chronic itch and promote itch sensations, in both primary sensory neurons and the skin. Second, the signaling pathways in the skin and the peripheral nervous system that initiate and sustain chronic itch conditions remain unknown. Finally, the contribution of the itch-scratch cycle, in which repetitive scratching worsens itch symptoms, to the progression of chronic itch has not been examined thoroughly. Therefore, there is an urgent need to

Received Nov. 15, 2012; revised April 17, 2013; accepted April 19, 2013.

Author contributions:S.R.W., A.M.N., D.M.O., E.A.L., and D.M.B. designed research;S.R.W., A.M.N., L.B., and D.E. performed research; S.R.W., A.M.N., and T.M. analyzed data; S.R.W. and D.M.B. wrote the paper.

This work was supported by the National Institute of Arthritis and Musculoskeletal and Skin Diseases-National Institutes of Health (Grant \#R01 AR051219 to E.A.L. and Grant \#R01 AR059385 to D.M.B.), the McNair Scholars Program (fellowship to A.M.N.), and the National Science Foundation (fellowship to S.R.W.). Histology was performed with support from the Columbia University Skin Disease Research Center Tissue Culture and Histology Core and Advanced Imaging Core (supported by National Institutes of Health Grant \#P30AR044535) and the Herbert Irving Comprehensive Cancer Center Confocal and Specialized Microscopy Shared Resource (supported by National Institutes of Health Grant \#P30CA013696).

The authors declare no competing financial interests.

Correspondence should be addressed to Diana Bautista, University of California, Department of Molecular and Cell Biology, 142 Life Sciences Addition \#3200, Berkeley, CA 94720-3200. E-mail: dbautista@berkeley.edu.

DOI:10.1523/JNEUROSCI.5318-12.2013

Copyright $\odot 2013$ the authors $\quad 0270-6474 / 13 / 339283-12 \$ 15.00 / 0$ better understand the cellular and molecular mechanisms underlying chronic itch.

A variety of cell types contribute to chronic itch pathologies and sensations. In the skin, tissue-resident cells such as keratinocytes and cells that infiltrate during inflammation, such as lymphocytes, mast cells, and eosinophils, release pruritogens that activate primary afferent neurons (Ikoma et al., 2006). These pruritogens are detected by the free nerve endings of primary afferent $C$-fibers located within the epidermis (Ikoma et al., 2006). Itch is mediated by both histaminesensitive and histamine-insensitive C-fibers, although most forms of chronic itch are insensitive to antihistamine treatment and are mediated by histamine-insensitive neurons (Jeffry et al., 2011; Han et al., 2013).

The ion channel TRPA1 is required for acute histamineindependent itch (Wilson et al., 2011). However, whether TRPA1 ion channels are required for chronic itch has not been examined. Using a mouse cheek model of chronic itch adapted from the model used by Miyamoto et al. (2002b), we show that scratching evoked by a dry skin model is abolished in TRPA1-deficient animals. This model recapitulates many of the pathophysiological hallmarks of chronic itch that are observed in prevalent human diseases such as psoriasis, including robust scratching, extensive epidermal hyperplasia, and changes in gene expression in the skin (Bowcock and Cookson, 2004). We provide clear evidence that TRPA1-expressing sensory neurons drive all of these dry-skinevoked phenotypes. In addition, we show for the first time that a model of chronic itch leads to significant expressional changes in the sensory neurons that innervate the affected skin. Finally, we demonstrate that dry, itchy skin triggers TRPA1-dependent hyperplasia in both the presence and absence of scratching. Remarkably, TRPA1 is required not only for transduction of chronic itch signals to the CNS, but also for the changes in gene expression that we observed in both neurons and skin. 
A

\begin{tabular}{|lr|} 
DRY SKIN PROTOCOL \\
\hline DAY 0 - SHAVE \\
& 9 AM \\
DAY 1 - AEW & 5 PM \\
& 9 AM \\
DAY 2 - AEW & 5 PM \\
& 9 AM \\
DAY 3 - AEW & 5 PM \\
RECORD \& HISTOLOGY \\
DAY 4 - AEW & 9 AM \\
& 5 PM \\
& 9 AM \\
DAY 5 - AEW & 5 PM \\
RECORD \& HISTOLOGY
\end{tabular}

D
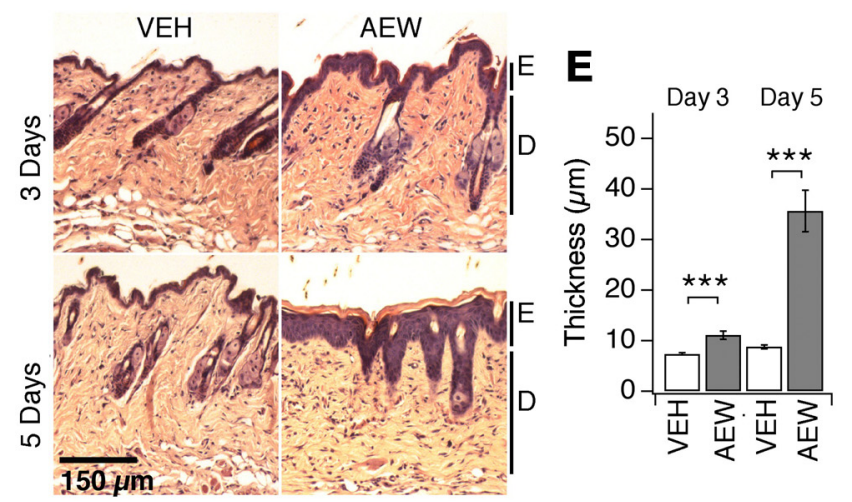

Figure 1. Cheek model of dry skin pruritus induces scratching and epidermal thickening. $A$, Time course for the dry skin assay in the mouse cheek. First day: the right cheek of each mouse was shaved. Days one to five: the shaved cheek was treated twice daily with a 1:1 mixture of acetone and ether, followed by water. Scratching behaviors were recorded for $20 \mathrm{~min}$ on days three and five after the second AEW treatment. Mouse cheeks were removed for histological analysis following recording on either day three or day five. $\boldsymbol{B}$, Photo displaying the area of treatment in the cheek model of itch $C$, Scratching behaviors were observed on day three and day five of cheek treatment. The total time spent scratching was quantified for $20 \mathrm{~min}$. Application of vehicle (VEH, water) failed to elicit scratching or wiping. All error bars represent SEM ( $n \geq 12$ mice/group, ${ }^{* *} p<0.01$, one-way ANOVA). $D$, H\&E-stained cheek skin sections from mice treated for $3 \mathrm{~d}$ (top) or $5 \mathrm{~d}$ (bottom) with AEW on ipislateral (right) and VEH on contralateral cheeks (left). E indicates epidermis; D, dermis. $\boldsymbol{E}$, Thickness of nucleated epidermal layers was quantified from AEW-treated and VEH-treated skin. Means \pm SEM are shown $(n=16-24$ sections from two mice per group, ${ }^{* * *} p<0.002$, Student's two-tail $t$ test).

\section{Materials and Methods}

Mice and behavior. All experiments were performed on male mice, 8-14 weeks of age. Female mice were not used due to effects of the estrus cycle on itch behaviors. Mice (20-35 g) were housed with a $12 \mathrm{~h}$ light-dark cycle at $21^{\circ} \mathrm{C}$. For assessing dry-skin-evoked itch behaviors in the mouse cheek, each cheek was shaved (Fig. $1 B$ ) and treated twice daily with a cotton swab immersed in either a 1:1 mixture of acetone and ether or water for $15 \mathrm{~s}$, followed by water for $30 \mathrm{~s}$ for a duration of either 3 or $5 \mathrm{~d}$. For assessing dry-skin-evoked itch behaviors in the mouse caudal back, the mouse back was shaved (Fig. $1 E$ ) and treated twice daily with a cotton swab immersed in either a 1:1 mixture of acetone and ether or water for $15 \mathrm{~s}$, followed by water for $30 \mathrm{~s}$ for a duration of either 3 or $5 \mathrm{~d}$. For resiniferatoxin (RTX) treatments, RTX $(100 \mu \mathrm{g} / \mathrm{ml}, 10 \mu \mathrm{l}$ in $0.05 \%$ ascorbic acid, and 7\% Tween 80 vehicle) was injected subcutaneously into the cheek $3 \mathrm{~d}$ before the first acetone, ether, and water (AEW) treatment. All mice were videotaped for $25 \mathrm{~min}$ to assess scratching. The amount of time each mouse spent scratching was quantified over a 20 min period. One bout of scratching was defined as an episode in which a mouse lifted its paw and scratched continuously for any length of time until the paw was returned to the floor. Mustard oil (10\% in PBS, 377430;
Sigma) was applied topically with a cotton swab to shaved mouse cheeks. Nocifensive behavior was quantified for $2 \mathrm{~min}$ after application. Behavioral scoring was performed while the observer was blind to the experimental condition. All experiments were performed under the policies and recommendations of the International Association for the Study of Pain and were approved by the University of California, Berkeley, Animal Care and Use Committee.

Histology. Skin specimens were dissected immediately after animals were killed and were then fixed in $4 \%$ paraformaldehyle overnight at $4^{\circ} \mathrm{C}$, dehydrated in $70 \%$ ethanol, and embedded in paraffin. Sections $(8 \mu \mathrm{m})$ were stained with H\&E or with rabbit anti-keratin-6 (KRT6) polyclonal antibodies (Covance), followed by immunoperoxidase labeling. Slides were imaged with a bright-field microscope outfitted with $10 \times, 0.3 \mathrm{nu}$ merical aperture (NA) and 20×, 0.4 NA lenses and an Axiocam color CCD camera (AxioObserver.Z1; Zeiss). All specimens were blinded with respect to genotype and treatment before imaging. The thickness of nucleated epidermal layers was measured from $20 \times$ bright-field images taken at $2-3$ random fields per section using ImageJ software.

Real-time quantitative PCR. Total RNA from skin was extracted using TRIzol reagent (Invitrogen) according to the manufacturer's specifications; $500 \mathrm{ng}$ of total RNA was used to generate cDNA using SuperScript III Reverse Transcriptase (Invitrogen). Real-time PCR was performed using SYBR GreenER qPCR SuperMix for ABI PRISM (Invitrogen) on a StepOnePlus ABI machine. To determine gene expression in keratinocytes, threshold cycles for each transcript $(\mathrm{Ct})$ were normalized to GAPDH $(\Delta \mathrm{Ct})$. Calibrations and normalizations were performed using the $2^{-\Delta \Delta \mathrm{Ct}}$ method in which GAPDH was used as the reference gene, samples from vehicle-treated mice were used as the calibrator, and $\Delta \Delta \mathrm{Ct}=[(\mathrm{Ct}$ (target gene $)-\mathrm{Ct}$ (reference gene $)]-[\mathrm{Ct}$ (calibrator) $\mathrm{Ct}$ (reference gene)]. Real-time PCR measurements were performed in triplicate.

Microarray. Trigeminal ganglia (TG) were removed from either wildtype C57BL6 or Trpa1 ${ }^{-1-}$ C57BL6 6- to 8-week-old mice treated with either AEW or vehicle for $5 \mathrm{~d}$ and RNA was isolated with TRIzol (Invitrogen) according to the manufacturer's protocol. RNA integrity was confirmed with an Agilent 2100 BioAnalyzer. RNA (100 ng) was used to make cRNA and samples were analyzed for gene expression with Affymetrix Mouse Genome 430.2 GeneChip arrays, which cover transcripts and variants from 34,000 well characterized mouse genes using standard Affymetrix reagents and protocols. Probe sets on this array are derived from sequences from GenBank and dbEST. Samples from three independent mice from each group were analyzed using one microarray per biological sample. Microarray data were normalized using the GCRMA algorithm (Bolstad et al., 2003; Irizarry et al., 2003a; Irizarry et al., $2003 \mathrm{~b})$; ratios of normalized probe set intensity values were calculated for each sample pair, in which $\mathrm{M}=\log 2[\operatorname{ICAM} 1(+) / \operatorname{ICAM} 1(-)]$, and then averaged among the three replicate pairs. Fold change was calculated to compare AEW- and VEH-treated mice within the same group (fold change = average AEW $\mathrm{M}$ value/average $\mathrm{VEH} M$ value, e.g., WT AEW/WT VEH).

Data analysis. Data are shown as means \pm SEM. Statistical significance was evaluated using a one-way ANOVA followed by a Tukey-Kramer post hoc test, unpaired two-tailed Student's $t$ test for comparing difference between two populations, or paired two-tailed Student's $t$ tests for datasets containing in-animal controls.

\section{Results}

Cheek model of dry skin pruritus induces itch behavior and epidermal thickening

To determine whether TRPA1 plays a role in chronic itch, we developed and validated a cheek assay for analyzing the molecular and cellular mechanisms underlying dry-skin-evoked chronic itch. Previous studies have shown that topical application of AEW to the rostral back/neck area of mice for 3-7 d induces dry skin and increases scratching significantly (Miyamoto et al., 2002b; Nojima et al., 2003). However, injection of both algogens and pruritogens into the rostral back triggers scratching, making it difficult to distinguish between itch and pain behaviors (Shi- 
mada and LaMotte, 2008). This ambiguity confounds studies of pruritus because chronic itch lesions, which are described to be both painful and itchy, develop in chronic itch models (Yosipovitch and Samuel, 2008; Ljosaa et al., 2012). This uncertainty is particularly relevant when studying genes such as Trpal, which are implicated in both itch and pain (Bautista et al., 2006; Wilson et al., 2011). In the cheek model of acute itch, injection of algogens triggers wiping with the forelimbs, whereas injection of pruritogens leads to scratching with the hindlimbs (Shimada and LaMotte, 2008). We combined these approaches to develop a cheek model of AEW-evoked dry skin in which the acetone/ether mixture and water are applied to the mouse cheek for $5 \mathrm{~d}$ (Fig. $1 A, B)$.

We observed that, like AEW treatment in the rostral back/ neck, cheek AEW treatment significantly increased scratching starting on the third day of treatment that doubled by day five $($ DAY $3 \mathrm{VEH}=0 \pm 0 \mathrm{~s}$, DAY $3 \mathrm{AEW}=52.43 \pm 12.39 \mathrm{~s}$, DAY 5 $\mathrm{VEH}=4.00 \pm 5.23 \mathrm{~s}$, DAY 5 AEW $=114.33 \pm 22.76 \mathrm{~s}$; Fig. $1 C$ ). Consistent with previous studies in untreated mice, topical application of mustard oil, a TRPA1 agonist and algogen, to the cheek evoked robust nocifensive behaviors (cheek wiping, $20 \mathrm{~s}$ in 2 min), which were never observed during AEW treatment (Matta et al., 2008). These data show that the AEW-cheek model triggers robust itch behaviors in mice.

AEW treatment was shown previously to induce epidermal thickening in skin isolated from the nape of the neck, a hallmark of psoriatic chronic itch in humans (Miyamoto et al., 2002b). We performed quantitative histological analysis to investigate whether AEW-evoked itching is accompanied by keratinocyte hyperplasia in the cheek skin. To control for variability between mice, we modified our AEW protocol and treated one cheek with AEW and the contralateral cheek with water (vehicle). Cheek skin treated with AEW for $3 \mathrm{~d}$ showed a significant increase in the thickness of nucleated epidermal layers compared with vehicletreated contralateral cheeks $(\mathrm{VEH}=7.4 \pm 0.2 \mu \mathrm{m}, \mathrm{AEW}=$ $11.1 \pm 0.8 \mu \mathrm{m}$; Fig. $1 D, E)$. After $5 \mathrm{~d}$ of AEW treatment, the treated epidermis was $\sim 4$-fold thicker than the contralateral control skin $(\mathrm{VEH}=8.8 \pm 0.4 \mu \mathrm{m}, \mathrm{AEW}=35.6 \pm 4.1 \mu \mathrm{m}$; Fig. $1 E)$.

Epidermal hyperplasia may occur from dry skin treatment alone and/or from dry-skin-evoked scratching (Mihara et al., 2004; Hashimoto et al., 2004; Takaoka et al., 2007; Yamaoka et al., 2007; Sugimoto et al., 2007; Yamamoto et al., 2009; Hashimoto et al., 2011). To examine the contribution of scratching to AEWevoked hyperplasia, animals must be prevented from scratching the AEW-treated skin. We were unsuccessful in preventing AEW mice from scratching the cheek using all commercially available restraint methods. Unlike water-treated mice, AEW-treated mice were highly motivated to remove such restraints and succeeded in removing apparatuses within $24 \mathrm{~h}$. Therefore, we instead returned to the back model of dry skin to address this question, specifically focusing on a caudal area of the back, just rostral to the tail, which mice cannot directly access to scratch, bite, or wipe (Fig. 2A). Both the rostral and caudal back have been extensively used in rodents to study acute and chronic itch (Kuraishi et al., 1995; Rojavin et al., 1998; Andoh et al., 1998; Kim et al., 1999; Kamei and Nagase, 2001; Thomsen et al., 2002; Jinks and Carstens, 2002; Miyamoto et al., 2002a; Orito et al., 2004; Nakano et al., 2008; Yamaura et al., 2009; Suwa et al., 2011). For example, pruritogen injection into the caudal back was shown to cause a 3.4-fold increase in itch behavior adjacent to the injection site (off-site scratching) and 5.4-fold increase in the activity of cutaneous nerves innervating the caudal back (Maekawa et al., 2002). Likewise, an animal model of allergic chronic itch in the mouse
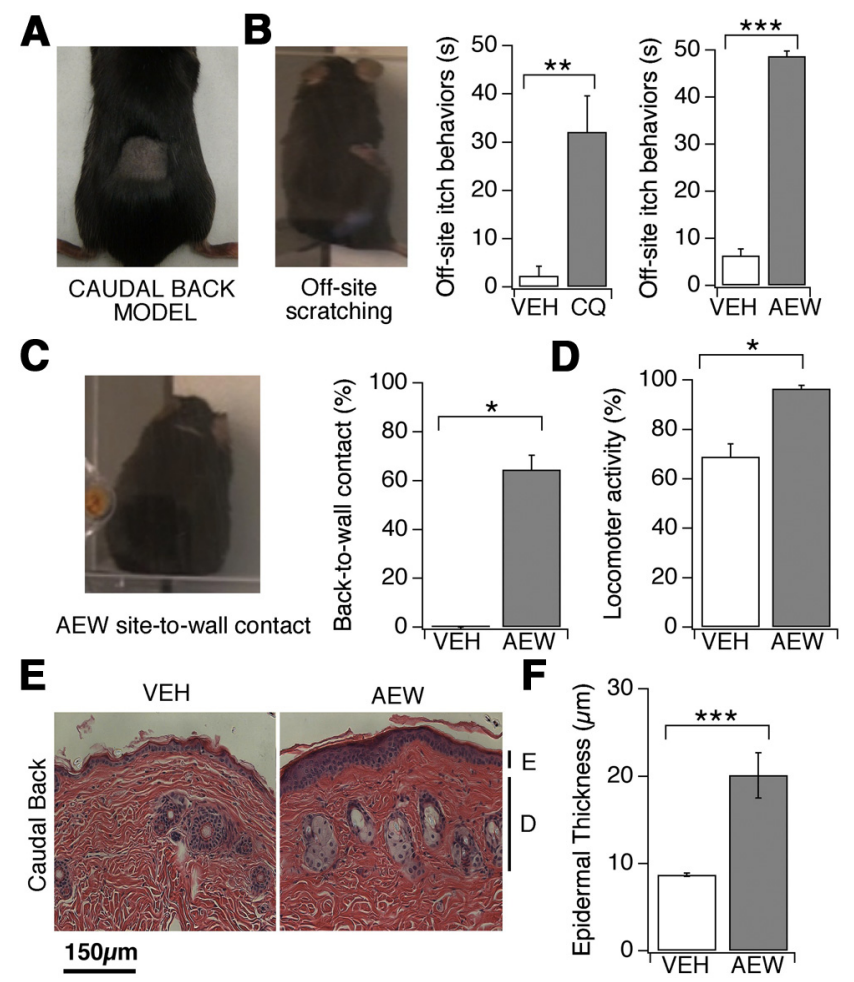

Figure 2. AEW caudal back model of dry skin pruritus induces off-site scratching, epidermal thickening, and increased locomotor activity. $\boldsymbol{A}$, Photo displaying the area of treatment in the caudal back model of itch. This assay produces dry skin, but the inaccessible location prevents scratching, wiping, or biting of the treated area. $\boldsymbol{B}$, Image displaying location of off-site scratching after treatment to the caudal back. Off-site scratching was observed in response to both acute subcutaneous injection of chloroquine (CQ) and chronic (5d) AEW treatment to the caudal back. AEW-evoked scratching behaviors were recorded on day five of treatment. After both treatments, the total time spent scratching or biting was quantified for $20 \mathrm{~min}$. Application of vehicle (VEH, water) failed to elicit scratching or biting toward any site. C, Image displaying AEW site-to-wall contact behavior. Site-to-wall behaviors were observed on day five of treatment. The total time spent in a back-to-wall configuration was quantified for $20 \mathrm{~min}$. Application of VEH failed to elicit back-to-wall contact. D, AEW-treated mice display a significant increase in locomotor activity in which they move and frequently attempt to contact the caudal back to the chamber wall. The percentage of time spent moving was quantified for $20 \mathrm{~min}$. $E$, H\&E-stained caudal back skin sections from mice treated for $5 \mathrm{~d}$ with AEW or VEH on the caudal back (VEH; water; left). E indicates epidermis; D, dermis. $\boldsymbol{F}$, Thickness of nucleated epidermal layers was quantified from AEW-treated and VEH-treated skin. All error bars represent SEM ( $n \geq 6$ mice) group, ${ }^{* * *} p<0.001$, one-way ANOVA).

back triggered itch behaviors, as well as epidermal hyperplasia and immune cell infiltration in the back skin of treated mice (Suwa et al., 2011). Indeed, a previous study in rodents showed that off-site scratching (within 5-17 $\mathrm{mm}$ of a pruritogen injection site) was antipruritic (Akiyama et al., 2012).

Several additional lines of data show that AEW on the caudal back is an effective model and that mice treated with AEW on the caudal back display itch behaviors. First, these mice spend a significant amount of time scratching areas of their body that can be reached (Fig. 2B). As observed on-site in the cheek and rostral back, mice treated with AEW on the caudal back showed off-site hair loss and skin lesions consistent with repetitive scratching. We observed similar off-site scratching after acute injection of the histamine-independent pruritogen, chloroquine (Fig. 2B). In addition, mice with AEW treatment on the caudal back spend a significant amount of time attempting to press their backs against the behavior chamber wall (Fig. 2C). Moreover, these mice appeared hyperactive, spending considerably more time moving around, with repetitive failed attempts to contact the site of treat- 
ment to the wall (Fig. 2D). Such behaviors were never observed in control mice. AEW also induces skin thickening on the caudal back, as it does on the cheek (Fig. $2 E, F)$ and rostral back (Miyamoto et al., 2002a). Interestingly, hyperplasia developed to a much lesser extent than that observed in the presence of scratching (Fig. $2 F$ ). Based on these results, we conclude that the AEW model induces itch behaviors, as well as scratch-dependent and -independent epidermal hyperplasia, and thus represents a valid model for studying the cellular and molecular mechanisms underlying chronic itch conditions.

\section{A subset of TRPV1-expressing sensory neurons is required for dry-skin-evoked} itch behaviors

Primary afferent sensory neurons that express the ion channels TRPV1 and TRPA1 are required for acute itch. TRPV1 is required for transducing histaminedependent itch and TRPA1 (expressed in a subset of TRPV1 fibers) is required for signaling in response to the histamineindependent pruritogens chloroquine and BAM8-22 (Imamachi et al., 2009; Mishra and Hoon, 2010; Mishra et al., 2011; Wilson et al., 2011). We thus assessed the role of TRPV1-positive fibers in the generation of dry-skin-evoked chronic itch behaviors. Previous studies have shown that ablation of TRPV1- and TRPV1/TRPA1-positive sensory neurons with capsaicin or the capsaicin analog RTX results in axonopathy and, consequently, suppression of acute pain and itch (Karai et al., 2004; Imamachi et al., 2009; Mitchell et al., 2010; Mishra and Hoon, 2010). Consistent with previous studies, RTX treatment of the cheek rendered mice insensitive to topical application of mustard oil, whereas control mice displayed robust wiping of the cheek (Bánvölgyi et al., 2004; Fig. 3A). No significant differences in skin thickness or integrity were observed between RTX- and water-treated mice (data not shown). Interestingly, RTX-treated mice displayed a significant decrease in AEW-evoked scratching behaviors compared with control mice on both day three and day five of AEW treatment (Fig. 3B). These data show that the TRPV1- and TRPV1/ TRPA1-positive sensory neurons are required for chronic AEW-evoked scratch behaviors and implicate TRPV1 and TRPA1 ion channels as candidate chronic itch transducers.

To gain insight into the molecules responsible for transducing chronic itch signals in TRPV1- and TRPV1/TRPA1-positive sensory neurons, we investigated whether dry skin alters gene expression in trigeminal neurons that innervate the mouse cheek.

A mice.
C

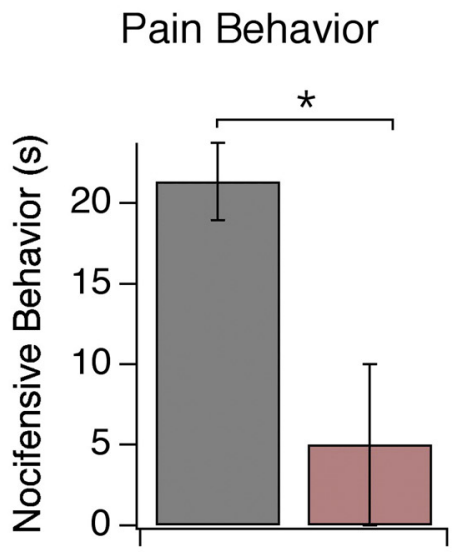

\section{B Itch Behavior}

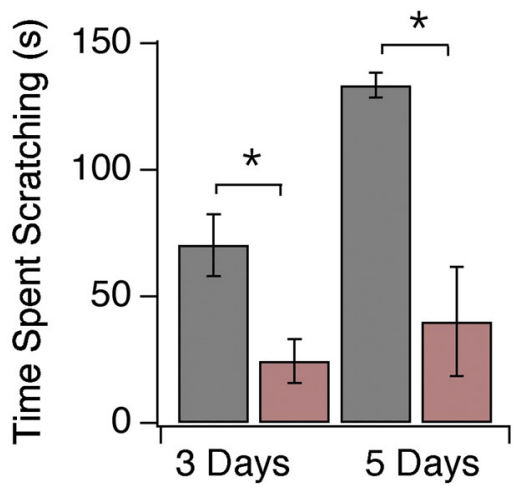

Figure 3. Sensory neurons are required for dry-skin-evoked itch behaviors. $A$, Mustard oil (M0, $10 \%$ in PBS)-evoked wiping was measured in wild-type, vehicle (CONTROL, $0.05 \%$ ascorbic acid, and 7\% Tween 80, black), or RTX-injected (RTX ABLATED; $1 \mu \mathrm{g} / \mathrm{ml}$ RTX in $0.05 \%$ ascorbic acid, and $7 \%$ Tween 80 , red) mice $3 \mathrm{~d}$ after injection. Nocifensive behavior was quantified for $2 \mathrm{~min}$. All error bars represent SEM ( $n \geq 4$ mice/genotype, ${ }^{*} p<0.05$ ). B, Dry-skin-evoked scratching was measured in wild-type vehicle (CONTROL, $0.05 \%$ ascorbic acid, and 7\% Tween 80, black) or RTX-injected (RTX ABLATED; $1 \mu \mathrm{g} / \mathrm{ml}$ RTX in 0.05\% ascorbic acid, and $7 \%$ Tween 80 , red) mice on days three and five of treatment. The total time spent scratching was quantified for 20 min. Error bars represent SEM $\left(n \geq 9\right.$ mice/genotype; $\left.{ }^{*} p<0.05\right)$ C, Gene expression was measured in whole TG isolated from VEH- and AEW-treated mice normalized to VEH-treated mice. Green indicates AEW-evoked increase in expression; magenta, AEW-evoked decrease in expression. Differentially expressed genes are clustered based on cellular function. Among differentially expressed receptors, the itch receptors MrgprA3 and Bdkr2 $\left(^{*}\right)$ were highly expressed in the TG of AEW-treated mice relative to VEH-treated

RNA from the TG of AEW - and vehicle-treated mice was hybridized to Affymetrix Mouse Genome 4302.0 microarrays. Of $\sim 34,000$ genes (45,102 probe sets), 1843 genes (2423 probe sets) were significantly differentially expressed. We focused on genes that belong to functional classes relevant to sensory neuron transduction, itch, and inflammation, as well as uncharacterized re- 
ceptors and ion channels (202 genes; Fig. 3C). These genes included the itch receptors Mas-related G-protein coupled receptor A3 (MrgprA3) and Protease Activated Receptor-2 (PAR2) and the inflammatory bradykinin receptor (Bdkr2; von Banchet et al., 2000; Bautista et al., 2006; Shimada et al., 2006; Stefansson et al., 2008; Liu et al., 2009; Russell et al., 2010; Han et al., 2013; Grastilleur et al., 2013), all of which were more highly expressed in the TG of AEW-treated mice compared with VEH-treated mice (Fig. $3 C$, green stars). We and others have shown that activation of MrgprA3, PAR2, and a Bdkr family member (Bdkr1) lead to opening of the ion channel TRPA1 and that TRPA1 activation is required for MrgprA3-evoked itch and Bdkr1-evoked pain behaviors in mice (Bautista et al., 2006; Dai et al., 2007; Wilson et al., 2011). These data, combined with the role of TRPAl in acute histamine-independent itch, strongly implicate a role for TRPA1 in chronic itch.

TRPA1 is required for dry-skin-evoked itch behaviors and morphological changes in the skin

We next investigated the role of TRPA1 in mediating chronic itch behaviors in mice. Trpa1 $1^{-1-}$ and wild-type littermates were treated using the AEW cheek assay. AEW treatment triggered prolonged periods of scratching in wild-type mice (DAY 3 $\mathrm{VEH}=0 \pm 0 \mathrm{~s}$, DAY $3 \mathrm{AEW}=52.43 \pm 12.39 \mathrm{~s}$, DAY $5 \mathrm{VEH}=$ $4.00 \pm 5.23 \mathrm{~s}$, DAY $5 \mathrm{AEW}=114.33 \pm 22.76 \mathrm{~s}$; Fig. 4A, black); this scratching behavior was significantly reduced in TRPA1deficient mice $\left(\mathrm{Al}^{-1-}\right.$ DAY $3=7.5 \pm 2.5 \mathrm{~s}, \mathrm{Al}^{-1-}$ DAY $5=36.7 \pm$ $10.39 \mathrm{~s}$; Fig. $4 A$, red). In contrast, no significant differences in itch behaviors were observed between $\operatorname{Trpv1} 1^{+/+}$mice and Trpv1 $1^{-1-}$ (gray) littermates $\left(\mathrm{V1}^{-1-}\right.$ DAY $3=45.12 \pm 11.23 \mathrm{~s}, \mathrm{V1}^{-1-} \mathrm{DAY}$ $5=98.76 \pm 15.71 \mathrm{~s} ;$ Fig. $4 A$ ) or between $\mathrm{TRPV1}^{+/+}$and TRPA $1^{+/+}$animals. These experiments demonstrate that TRPA1 is selectively required for dry-skin-evoked chronic itch behaviors.

We next investigated whether acute inhibition of TRPA1 attenuates AEW-evoked scratching. The TRPAl inhibitor HC030031 was injected subcutaneously into the cheek immediately before recording AEW-evoked itch behaviors on treatment days three and five. Like genetic ablation of TRPA1, HC-030031 significantly reduced AEW-evoked itch behaviors (Fig. 4B). These data suggest that TRPA1 is required for the transduction of itch sensation in chronic conditions. We also found that TRPA1 promoted epidermal hyperplasia in this chronic itch model. In wildtype mice, $5 \mathrm{~d}$ treatment with AEW triggered a 4 -fold increase in the thickness of nucleated epidermal layers compared with vehicle-treated contralateral skin samples $(\mathrm{VEH}=8.7 \pm 0.6 \mu \mathrm{m}$, $\mathrm{AEW}=32.5 \pm 6.4 \mu \mathrm{m}$; Fig. $4 C, D$, gray). TRPA1 ${ }^{-1-}$ mice showed comparatively modest epidermal hyperplasia in response to AEW $(\mathrm{VEH}=9.7 \pm 2.1 \mu \mathrm{m}, \mathrm{AEW}=20.4 \pm 1.9 \mu \mathrm{m})$ and the magnitude was significantly less than in wild-type littermates $\left(\mathrm{WT}=375 \pm 50 \%, \mathrm{Al}^{-1-}=210 \pm 20 \%\right.$; Fig. $4 D$, red). These data show that TRPA1 promotes disturbances in epidermal homeostasis in chronic itch and supports a role for TRPA1, not only in the transduction of, but also in the development of dry-skinevoked itch.

Although dry skin treatment alone caused epidermal thickening, the itch-scratch cycle further promoted hyperplasia (Fig. $1 F)$. Therefore, a lack of scratching behaviors may contribute to the decreased epidermal thickening in TRPA1-deficient mice. Indeed, dry-skin evoked-epidermal hyperplasia was not significantly different between the "no-scratch" skin versus TRPA1deficient skin (Fig. 4D, gray). However, this does not rule out the possibility that TRPA1 may also directly influence hyperplasia via signaling between sensory neurons and keratinocytes. We next

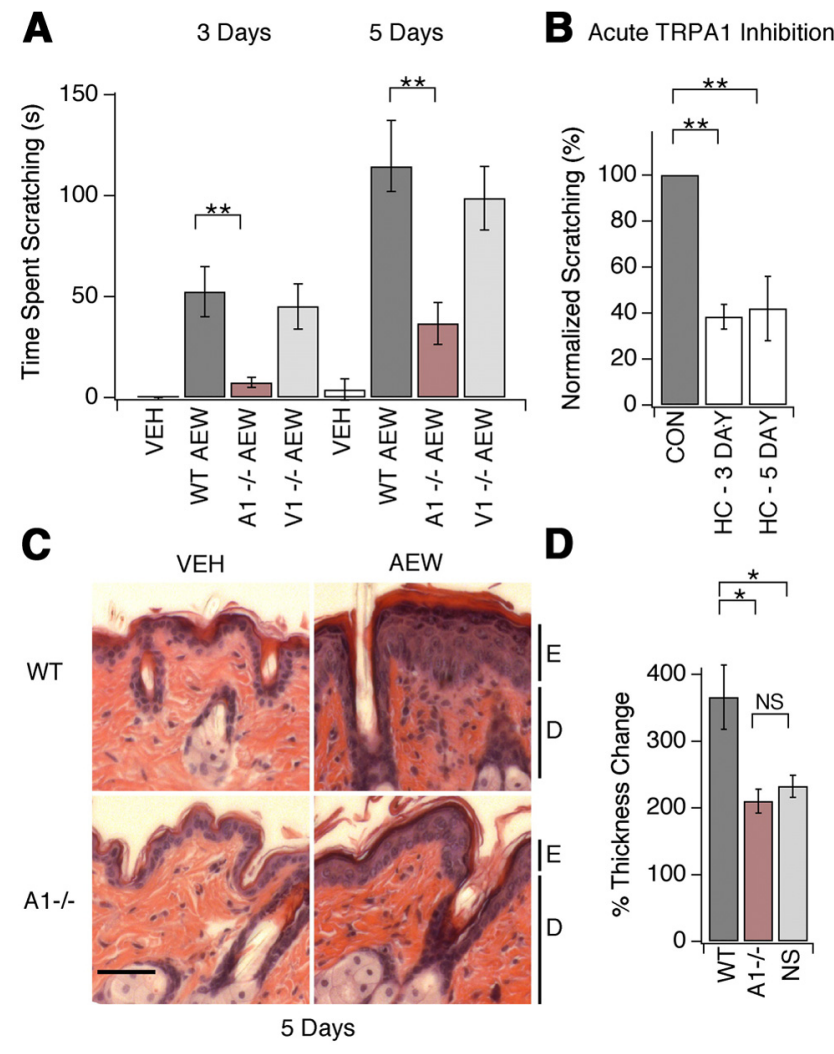

Figure 4. TRPA1 is required for dry-skin-evoked itch behaviors and morphological changes in the skin. $\boldsymbol{A}$, Dry-skin-evoked scratching was measured in wild-type (WT AEW; black), TRPV1 $^{-1-}$ (V1 AEW; gray), and TRPA1 ${ }^{-1-}$ (A1 AEW; red) mice after 3 and 5 d of AEW treatment to the cheek. The total time spent scratching was quantified for $20 \mathrm{~min}$. Treatment with vehicle on wild-type mice (VEH, water) failed to elicit scratching or wiping (VEH; white). All error bars represent SEM ( $n \geq$ mice/genotype, $\left.{ }^{* *} p<0.01\right)$. $\boldsymbol{B}$, Dry-skin-evoked scratching was measured in wild-type mice on AEW treatment on days three and five immediately after ( $\leq 2 \mathrm{~min}$ ) subcutaneous injection with control PBS (CON) or the TRPA1 inhibitor HC-030031 (HC). The total time spent scratching was quantified for 20 min postinjection and normalized to $\mathrm{CON}$-treated mice. All error bars represent SEM ( $n \geq 9$ mice/genotype or treatment, $\left.{ }^{* *} p<0.01\right)$. C, H\&Estained skin sections from wild-type mice (WT; top) and TRPA $1^{-I-}$ littermates $\left(\mathrm{A}^{-I-} ;\right.$ bottom) treated ipsilaterally with AEW (left) and contralaterally with VEH. Eindicates epidermis; D, dermis. $\boldsymbol{D}$, The increase in epidermal thickness induced by AEW was quantified from four to five mice per condition. NS indicates the "no scratching" condition in the caudal back model. Means \pm SEM are shown $\left({ }^{*} p=0.01\right.$, Student's two-tail $t$ test).

examined dry-skin-evoked gene expression changes in the skin to determine the relative contribution of scratching and TRPA1 to the phenotypic changes observed in the skin.

\section{TRPA1 is required for dry-skin-evoked expressional changes in the skin}

Significant changes in epidermal gene expression are observed in the skin of patients with chronic itch (Bowcock and Cookson, 2004; Olsson et al., 2006; Theoharides et al., 2010). Studies have shown that the itch-scratch cycle contributes to the chronic itch disease-associated changes observed in patient skin (Mihara et al., 2004; Hashimoto et al., 2004; Takaoka et al., 2007; Yamaoka et al., 2007; Sugimoto et al., 2007; Yamamoto et al., 2009; Hashimoto et al., 2011). Does the AEW model of chronic itch induce expressional changes in the skin? If so, are these changes mediated by dry skin alone, by the dry-skin-evoked itch-scratch cycle, or both? And to what extent does TRPA1 contribute to AEW-evoked expression changes? To answer these questions, we used microarray analysis to examine AEW-evoked gene expression in skin. 


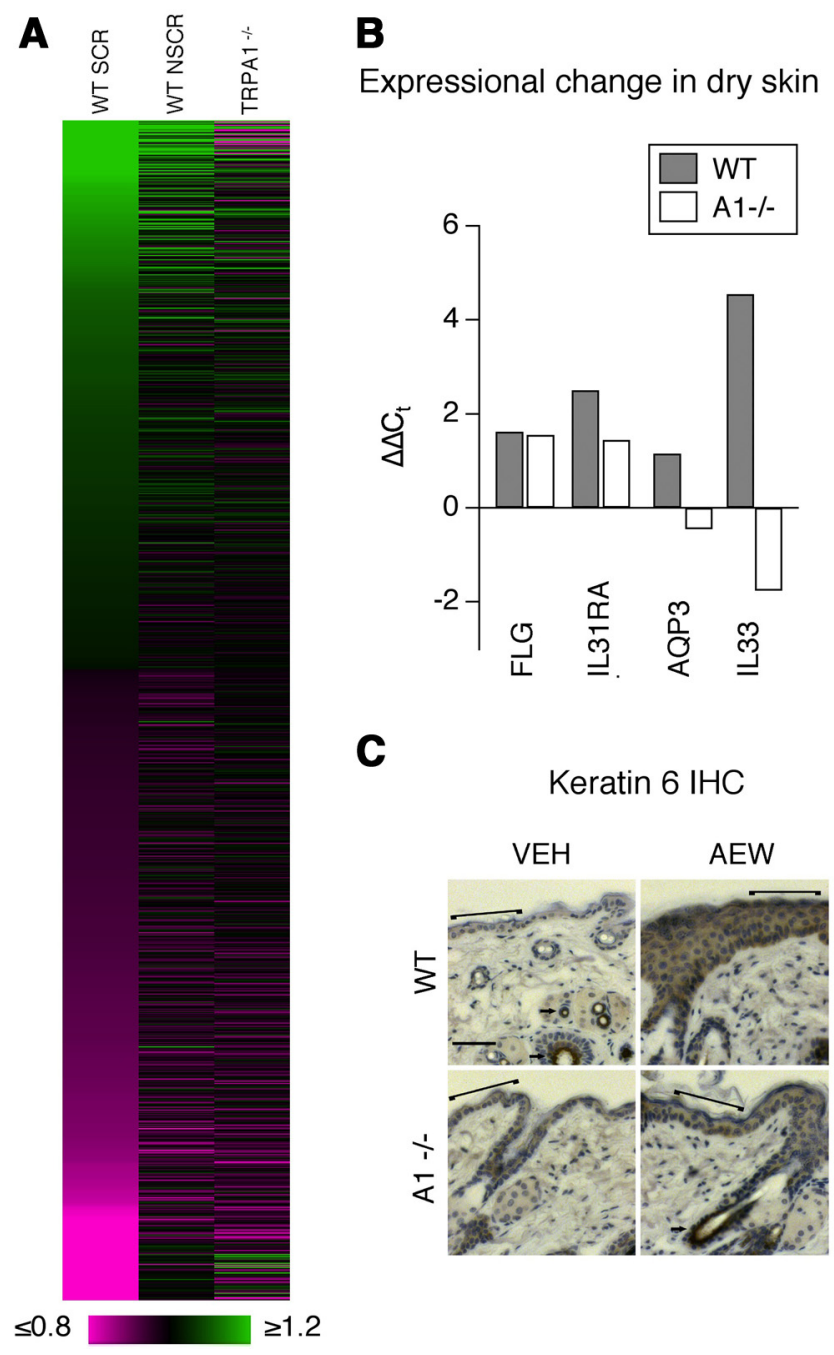

Figure 5. TRPA1 is required for dry-skin-evoked expressional changes in the skin. $A$, Gene expression was measured in cheek skin biopsies isolated from VEH- or AEW-treated TRPA $1^{+/+}$ mice that were free to scratch (WT SCR), and TRPA1 ${ }^{-1-}$ mice. Gene expression was also measured in caudal back skin biopsies in which scratching was prevented (WT NSCR). The AEW gene expression data are normalized to VEH for each genotype and treatment area. Green indicates the AEW-evoked increase in expression; magenta, the AEW-evoked decrease in expression. All genes significantly altered in WT mice are shown $(p<0.05)$. $\boldsymbol{B}$, Changes in gene expression with AEW treatment for FLG, IL31RA, AQP3, and IL33 in WT (black) and $\mathrm{A}^{-1-}$ (white) mice as measured by quantitative $\mathrm{PCR}$. Expression is reported as $\Delta \Delta \mathrm{Ct}$. $\mathrm{C}$, Micrographs of WT and $\mathrm{A} 1^{-1-}$ skin are stained with KRT6 (brown). In VEH-treated skin, KRT6 is localized to hair follicles (arrows), whereas AEW-treated skin shows induction of KRT6 in the interfollicular epidermis (brackets). Nuclei are stained in blue. Scale bar, $50 \mu \mathrm{m}$.

We compared changes in expression between AEW- and vehicle-treated skin in three sets of animals: wild-type mice that were free to scratch the patch of dry skin on their cheek, wild-type animals that could not scratch the patch of dry skin on their back, and TRPA1-deficient animals that were free to scratch the patch of dry skin on their cheek (however, as shown in Figure 4, these mice display significantly reduced itch behaviors). Vehicletreated skin isolated from the cheek and caudal back displayed few differences in gene expression $(<2 \%)$. However, to compare gene expression among all groups, expression was normalized to vehicle treatments within the same tissue (e.g., AEW-treated back skin normalized to VEH-treated back skin; Fig. 5A). Overall, AEW treatment of wild-type mice triggered a significant change in expression in 9340 (14,884 probe sets) genes (Fig. 5A). We categorized these AEW genes into three groups: (1) TRPA1dependent genes (those that do not display altered expression in the absence of TRPA1), (2) scratch-dependent genes (those that do not display altered expression in the absence of scratching), and (3) scratch- and TRPA1- dependent genes (those that do not display altered expression in the absence of TRPA1 and scratching). Quantitative PCR validated expressional changes of several genes that were previously linked to chronic itch (Sonkoly et al., 2006; Olsson et al., 2006; Theoharides et al., 2010; Kawasaki et al., 2011; Nakahigashi et al., 2011). For example, the scratch-independent gene Fillagrin (FLG) is upregulated by AEW treatment in a TRPAl-independent manner. The scratch-independent genes Aquaporin 3 (AQP3) and interleukin 33 (IL33) were also differentially expressed in AEW-treated versus VEH-treated mouse skin and were TRPA1 dependent. Likewise, the scratch-dependent gene IL31 receptor A (IL31RA) was upregulated in AEW-treated versus VEH-treated mouse skin, but not in TRPA1-deficient skin. Antibody staining was also used to validate the enriched expression of the scratchindependent gene KRT6 (Fig. 5C), a hair follicle keratin upregulated in the interfollicular epidermis upon injury (Rotty and Coulombe, 2012). Microarray analysis showed that AEW increased the KRT6 signal intensity 9-fold in wild-type skin, but only 4-fold in TRPA1 ${ }^{-1-}$ skin. Consistent with these data, immunohistochemistry demonstrated an upregulation of KRT6 protein in the interfollicular epidermis, but not in the hair follicles of AEW-treated skin (Fig. 5C). Although upregulation was observed in both genotypes, KRT6 expression was more abundant in the WT than in TRPA $1^{-1-}$ interfollicular epidermis (Fig. 5C).

Of the upregulated genes, most were scratch-dependent (76\%), suggesting that the itch-scratch cycle contributes greatly to AEW-evoked changes in the skin (Fig. 6A). The majority of the upregulated genes (77\%) were also TRPA1-dependent (Fig. 6A). TRPA1 also contributed to scratch-independent expressional changes; of the $24 \%$ of AEW genes that were not affected by scratching, 45\% were TRPA1 dependent. We next analyzed a subset of the genes affected by itch that were previously implicated in processes related to chronic itch (195 genes); this subset includes genes altered by pathological pruritic diseases, genes controlling neuronal growth, and genes involved in itch signal transduction (Fig. 6B). Within this subset of itch genes, $42 \%$ were dependent solely on TRPA1, compared with only $9 \%$ percent observed for the larger dataset inclusive of all genes; only $57 \%$ of the itch subset were scratch dependent, compared with $76 \%$ of the overall dataset of genes, suggesting that independently of the role of TRPA1 in scratching, TRPA1 may play a more direct role in the regulation of genes related to chronic itch disease.

To gain insight into the biological functions affected by dry, itchy skin and the role of scratching and TRPA1 in promoting these changes, we performed Gene Ontology (GO) analysis to identify classes of genes that are significantly affected by AEW treatment (Table 1). Most GO terms were both scratch- and TRPA1-dependent and were no longer enriched in the absence of TRPA1 or scratching. These include many categories, such as regulation of epithelial cell proliferation, regulation of axon extension, and activation of immune response. However, GO terms for water transport were only dependent on TRPA1, which was surprising because increased water loss, which has been linked to the water channel AQP3, is a hallmark of chronic itch skin and disruption of skin barrier function (Yosipovitch, 2004; Olsson et al., 2006; Hon et al., 2008; Nakahigashi et al., 2011; Lee et al., 2012). 
A

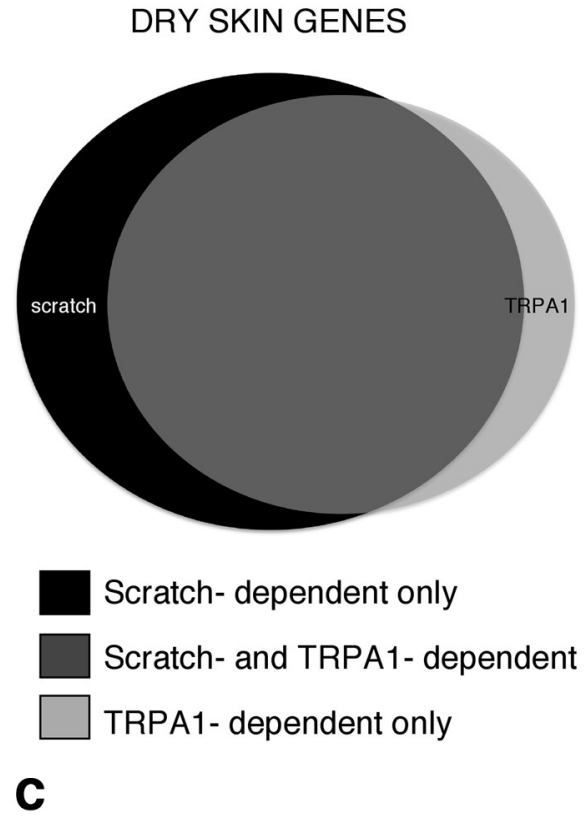

DRY SKIN GENES PREVIOUSLY
IMPLICATED IN ITCH

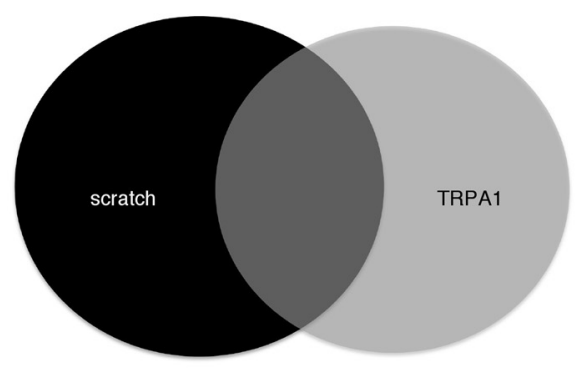

B

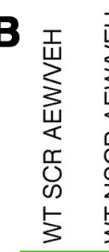

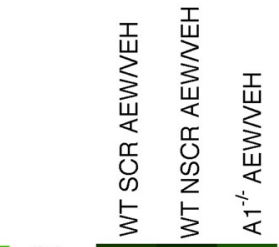

\section{.}

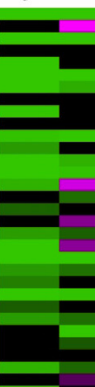

.

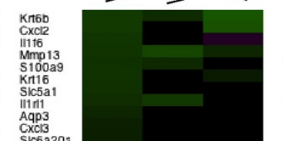

$\leq 0.8$

$\geq 1.2$

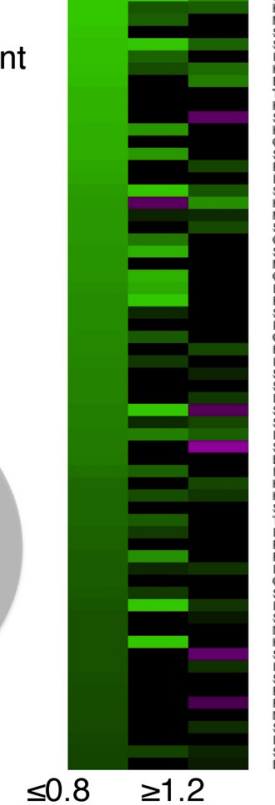

(1)

Figure 6. TRPA1 promotes scratch-dependent and scratch-independent expressional changes in the skin. $\boldsymbol{A}$, Venn diagram displaying relative numbers of scratch-dependent, TRPA1-dependent, and scratch- and TRPA1-dependent genes significantly modulated in WT AEW mouse cheek skin. $B$, Analysis of a subset of genes that were previously implicated in processes related to chronic itch to determine dependence on scratching and/or TRPA1 (Fig. 5A). Green indicates AEW-evoked increase in expression; magenta, AEW-evoked decrease in expression. C, Venn diagram displaying relative numbers of scratch-dependent, TRPA1dependent, and scratch- and TRPA1-dependent itch-related genes significantly modulated in WT AEW mouse cheek skin.

\section{Discussion}

Our findings demonstrate a new role for TRPA1 in multiple facets of chronic itch. Here we used a dry skin mouse model of itch to probe the mechanisms of chronic itch in skin and sensory neurons. We adapted the dry skin model to the cheek, which allowed for the distinction between itch and pain behaviors (Miyamoto et al., 2002b). Then we adapted the model to the caudal back, an area that the mouse cannot access for scratching, biting, or wiping, to examine mechanisms of chronic itch in the absence of scratching. The cheek model displays many of the phenotypes observed in human chronic itch, including itch behaviors, epidermal hyperplasia, and expressional changes in the skin (Bowcock and Cookson, 2004). This model triggers increased expression of many genes implicated in human pruritic dry skin conditions: AQP3, Ccl27, FLG, and Tnc for atopic dermatitis;

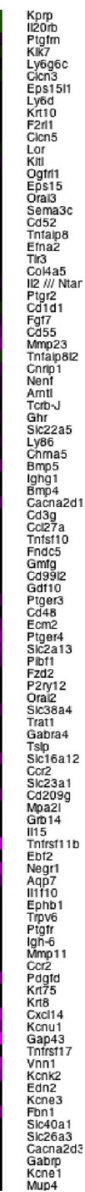

IL33, Ccl20, Cxcl2, Cxcr2, lipocalin, and Slc9a3r1 for psoriasis; and S100a9, involucrin, and Ccr5, which have been implicated in both psoriasis and atopic dermatitis (Bowcock and Cookson, 2004; Olsson et al., 2006; Theoharides et al., 2010). Because the cheek AEW model promotes dry itchy skin and the itchscratch cycle, in which repetitive scratching worsens chronic itch symptoms, we sought to look at these phenotypes in isolation (Mihara et al., 2004; Hashimoto et al., 2004; Takaoka et al., 2007; Yamaoka et al., 2007; Sugimoto et al., 2007; Yamamoto et al., 2009; Hashimoto et al., 2011).

We performed, for the first time, a comparison of hyperplasia and gene expression changes in itchy, yet unscratched skin. The ideal experiment to determine the role of scratching in AEW-evoked hyperplasia and gene expression would be to compare AEW-treated cheek skin isolated from mice that were permitted to or prevented from scratching. However, we were unsuccessful in preventing AEW mice from scratching the cheek using all commercially available restraint methods. We thus instead turned to the back model of dry skin to address this question, specifically focusing on a caudal area of the back just rostral to the tail, which is inaccessible. In the caudal back model, mice display off-site scratching, but the location of the AEW-treated skin is such that the mice cannot directly scratch, bite, or lick the affected skin.

The caudal back model induced a $230 \%$ increase in epidermal thickness, whereas the cheek model induced a $350 \%$ increase. Like the hyperplasia, dry-skinevoked gene-expression changes in the skin were not entirely dependent on the itchscratch cycle, because $24 \%$ of the genes upregulated in the cheek model were also upregulated in the caudal back model. These findings suggest that the itchscratch cycle contributes greatly to dryskin-evoked changes in the skin, but many changes also occur in the absence of scratching. One caveat with this interpretation is the assumption that cheek skin responds identically to AEW treatment as caudal back skin. We see no significant differences in baseline epidermal thickness and few differences in baseline gene expression between these different sites. However, it is possible that differences in the dermis or epidermis, the prevalence and/or distribution of itch-sensitive nerve fibers, or the resident immune cells that contribute to inflammation may vary between the cheek and the back. Regardless of any differences between the cheek and back, the genes identified in the caudal back AEW model represent the first candidate genes that are altered by dry, itchy skin independently of scratching.

Chronic itch patients often experience increased sensitivity to itch stimuli, as well as alloknesis, the perception of itch in re- 
Table 1. G0 terms are overrepresented in the skin of AEW-treated mice in a TRPA1- and scratch-dependent manner

\begin{tabular}{|c|c|c|c|c|}
\hline G0 term & GOID & $n$ & $\%$ & $p$-value \\
\hline \multicolumn{5}{|l|}{ Neuronal growth and development } \\
\hline Neurogenesis ${ }^{a}$ & 22008 & 49 & 7.2 & 4.96E-11 \\
\hline Neuron differentiation ${ }^{a}$ & 30182 & 35 & 7.6 & $9.32 \mathrm{E}-09$ \\
\hline Regulation of neuron differentiation ${ }^{a}$ & 45664 & 22 & 10.8 & $1.22 \mathrm{E}-08$ \\
\hline Neuron development ${ }^{a}$ & 48666 & 29 & 8.1 & $3.84 \mathrm{E}-08$ \\
\hline Generation of neurons $^{a}$ & 48699 & 47 & 7.4 & $6.17 \mathrm{E}-11$ \\
\hline Regulation of axon extension ${ }^{b}$ & 30516 & 8 & 26.7 & 5.66E-07 \\
\hline Regulation of axon extension ${ }^{b}$ & 30516 & 8 & 26.7 & 5.66E- -07 \\
\hline Negative regulation of axon extension ${ }^{b}$ & 30517 & 5 & 41.7 & $6.89 \mathrm{E}-06$ \\
\hline Negative regulation of axon extension ${ }^{b}$ & 30517 & 5 & 41.7 & $6.89 \mathrm{E}-06$ \\
\hline Regulation of axon extension involved in axon guidance ${ }^{b}$ & 48841 & 5 & 55.6 & 1.17E- -06 \\
\hline Regulation of axonogenesis ${ }^{b}$ & 50770 & 12 & 19.0 & $5.00 \mathrm{E}-08$ \\
\hline Water transport ${ }^{c}$ & 6833 & 6 & 40.0 & $1.04 \mathrm{E}-06$ \\
\hline Ion transport ${ }^{b}$ & 6811 & 151 & 21.0 & $3.47 \mathrm{E}-95$ \\
\hline 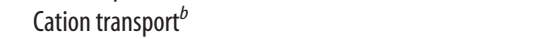 & 6812 & 114 & 21.0 & $3.68 \mathrm{E}-71$ \\
\hline Potassium ion transport $^{b}$ & 6813 & 36 & 23.7 & $8.36 \mathrm{E}-25$ \\
\hline Sodium ion transport ${ }^{b}$ & 6814 & 43 & 32.6 & $7.74 \mathrm{E}-36$ \\
\hline 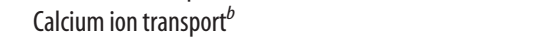 & 6816 & 22 & 16.9 & $1.71 \mathrm{E}-12$ \\
\hline Anion transport ${ }^{b}$ & 6820 & 42 & 29.6 & $4.59 \mathrm{E}-33$ \\
\hline Chloride transport $^{b}$ & 6821 & 18 & 27.7 & $2.30 \mathrm{E}-14$ \\
\hline Zinc ion transport $^{b}$ & 6829 & 10 & 40.0 & $2.28 \mathrm{E}-10$ \\
\hline Neurotransmitter transport ${ }^{b}$ & 6836 & 14 & 16.3 & $3.18 \mathrm{E}-08$ \\
\hline Amino acid transport ${ }^{b}$ & 6865 & 30 & 36.6 & 4.10E-27 \\
\hline Cellular ion homeostasis & 6873 & 38 & 10.9 & $5.03 \mathrm{E}-14$ \\
\hline Regulation of calcium ion transport ${ }^{b}$ & 51924 & 12 & 15.0 & 7.63E-07 \\
\hline $\begin{array}{l}\text { Regulation of calcium ion transport by v-gated calcium } \\
\text { channel }^{b}\end{array}$ & 51925 & 8 & 22.9 & 2.04E-06 \\
\hline Metal ion homeostasis ${ }^{b}$ & 55065 & 20 & 10.9 & $4.48 \mathrm{E}-08$ \\
\hline Di-, tri-valent inorganic cation homeostasis ${ }^{b}$ & 55066 & 23 & 10.7 & $6.68 \mathrm{E}-09$ \\
\hline Monovalent inorganic cation homeostasis ${ }^{b}$ & 55067 & 8 & 20.5 & 4.87E-06 \\
\hline Calcium ion homeostasis $^{b}$ & 55074 & 20 & 11.9 & $1.04 \mathrm{E}-08$ \\
\hline Calcium ion transmembrane transport $^{b}$ & 70588 & 12 & 22.2 & 7.91E-09 \\
\hline Divalent metal ion transport ${ }^{b}$ & 70838 & 24 & 17.1 & $1.25 \mathrm{E}-13$ \\
\hline Sodium ion export ${ }^{b}$ & 71436 & 14 & 38.9 & $8.51 \mathrm{E}-14$ \\
\hline Zinc ion transmembrane transport ${ }^{b}$ & 71577 & 6 & 50.0 & 2.05E-07 \\
\hline \multicolumn{5}{|l|}{ Epithelial growth and development } \\
\hline Response to wounding ${ }^{a}$ & 9611 & 64 & 17.3 & $1.86 \mathrm{E}-34$ \\
\hline Epidermal cell differentiation ${ }^{a}$ & 9913 & 12 & 24.5 & $2.39 \mathrm{E}-09$ \\
\hline Keratinocyte differentiation ${ }^{a}$ & 30216 & 11 & 24.4 & $1.14 \mathrm{E}-08$ \\
\hline Epithelial cell differentiation $^{a}$ & 30855 & 20 & 14.7 & $2.42 \mathrm{E}-10$ \\
\hline Wound healing $^{a}$ & 42060 & 21 & 16.2 & $1.38 \mathrm{E}-11$ \\
\hline Epithelium development $^{a}$ & 60429 & 41 & 12.2 & 7.45E-17 \\
\hline Morphogenesis of a branching epithelium ${ }^{a}$ & 61138 & 16 & 13.9 & 3.37E-08 \\
\hline Epidermis development ${ }^{b}$ & 8544 & 25 & 19.2 & $2.38 \mathrm{E}-15$ \\
\hline Keratinization ${ }^{b}$ & 31424 & 7 & 28.0 & 2.05E-06 \\
\hline Regulation of epithelial cell proliferation ${ }^{b}$ & 50678 & 13 & 16.9 & $6.29 \mathrm{E}-08$ \\
\hline Positive regulation of epithelial cell proliferation ${ }^{b}$ & 50679 & 8 & 20.5 & $\begin{array}{r}\text { 4.87E- } 06 \\
\text { (Table continues.) }\end{array}$ \\
\hline
\end{tabular}


Table 1. Continued

\begin{tabular}{|c|c|c|c|c|}
\hline G0 term & GOID & $n$ & $\%$ & $p$-value \\
\hline \multicolumn{5}{|l|}{ Prostanoid process } \\
\hline Prostaglandin biosynthetic process ${ }^{b}$ & 1516 & 5 & 45.5 & 4.11E-06 \\
\hline Prostanoid metabolic process $s^{b}$ & 6692 & 6 & 42.9 & $6.39 \mathrm{E}-07$ \\
\hline Prostanoid biosynthetic process $^{b}$ & 46457 & 5 & 45.5 & 4.11E-06 \\
\hline \multicolumn{5}{|l|}{ Synapse } \\
\hline Synaptic transmission ${ }^{b}$ & 7268 & 21 & 8.8 & $9.03 \mathrm{E}-07$ \\
\hline Negative regulation of secretion ${ }^{b}$ & 51048 & 10 & 14.3 & $9.96 \mathrm{E}-06$ \\
\hline \multicolumn{5}{|l|}{ Stimulus response } \\
\hline Regulation of response to external stimulus ${ }^{a}$ & 32101 & 21 & 12.3 & $2.54 \mathrm{E}-09$ \\
\hline Response to chemical stimulus ${ }^{a}$ & 42221 & 88 & 8.1 & 4.17E-22 \\
\hline Regulation of response to stimulus ${ }^{a}$ & 48583 & 53 & 12.3 & $1.73 \mathrm{E}-21$ \\
\hline Positive regulation of response to stimulus ${ }^{a}$ & 48584 & 31 & 13.7 & $2.01 \mathrm{E}-14$ \\
\hline Immune response & 6955 & 54 & 15.4 & $1.14 \mathrm{E}-26$ \\
\hline Regulation of cytokine production ${ }^{a}$ & 1817 & 19 & 12.6 & $9.70 \mathrm{E}-09$ \\
\hline Positive regulation of cytokine production ${ }^{a}$ & 1819 & 11 & 14.9 & $2.41 \mathrm{E}-06$ \\
\hline Immune system process ${ }^{a}$ & 2376 & 86 & 12.3 & $2.10 \mathrm{E}-34$ \\
\hline Immune system development $^{a}$ & 2520 & 26 & 8.6 & $6.05 \mathrm{E}-08$ \\
\hline Regulation of immune system process ${ }^{a}$ & 2682 & 49 & 13.1 & $3.48 \mathrm{E}-21$ \\
\hline Positive regulation of immune system process ${ }^{a}$ & 2684 & 38 & 15.8 & $1.71 \mathrm{E}-19$ \\
\hline Defense response $^{a}$ & 6952 & 58 & 13.1 & $6.46 \mathrm{E}-25$ \\
\hline Inflammatory response ${ }^{a}$ & 6954 & 43 & 18.9 & $3.52 \mathrm{E}-25$ \\
\hline Cytokine-mediated signaling pathway ${ }^{a}$ & 19221 & 21 & 24.1 & $3.30 \mathrm{E}-15$ \\
\hline Innate immune response ${ }^{a}$ & 45087 & 17 & 14.2 & $9.56 \mathrm{E}-09$ \\
\hline Leukocyte activation ${ }^{a}$ & 45321 & 23 & 9.8 & $3.31 \mathrm{E}-08$ \\
\hline Negative regulation of immune system process ${ }^{b}$ & 2683 & 13 & 14.6 & $3.64 \mathrm{E}-07$ \\
\hline Regulation of leukocyte activation ${ }^{b}$ & 2694 & 26 & 15.1 & $2.56 \mathrm{E}-13$ \\
\hline Positive regulation of leukocyte activation ${ }^{b}$ & 2696 & 22 & 19.6 & 7.15E-14 \\
\hline Regulation of immune effector process ${ }^{b}$ & 2697 & 19 & 17.1 & 4.57E-11 \\
\hline Negative regulation of immune effector process ${ }^{b}$ & 2698 & 7 & 25.9 & $3.62 \mathrm{E}-06$ \\
\hline $\begin{array}{l}\text { Regulation of production of molecular mediator of } \\
\text { immune response }^{b}\end{array}$ & 2700 & 10 & 25.0 & $4.21 \mathrm{E}-08$ \\
\hline Immune response-activating signal transduction ${ }^{b}$ & 2757 & 10 & 16.4 & $2.78 \mathrm{E}-06$ \\
\hline Immune response-regulating signaling pathway ${ }^{b}$ & 2764 & 12 & 18.5 & $7.21 \mathrm{E}-08$ \\
\hline Regulation of adaptive immune response ${ }^{b}$ & 2819 & 12 & 18.8 & $6.01 \mathrm{E}-08$ \\
\hline T-cell differentiation ${ }^{b}$ & 30217 & 12 & 15.2 & $6.64 \mathrm{E}-07$ \\
\hline Leukocyte chemotaxis $^{b}$ & 30595 & 10 & 31.3 & $3.84 \mathrm{E}-09$ \\
\hline Regulation of B-cell proliferation ${ }^{b}$ & 30888 & 14 & 38.9 & $8.51 \mathrm{E}-14$ \\
\hline Positive regulation of B-cell proliferation ${ }^{b}$ & 30890 & 13 & 48.1 & $2.19 \mathrm{E}-14$ \\
\hline Tumor necrosis factor-mediated signaling pathway ${ }^{b}$ & 33209 & 5 & 45.5 & 4.11E-06 \\
\hline T-cell activation ${ }^{b}$ & 42110 & 16 & 13.2 & 7.00E-08 \\
\hline Regulation of T-cell differentiation ${ }^{b}$ & 45580 & 11 & 22.0 & $3.73 \mathrm{E}-08$ \\
\hline Positive regulation of T-cell differentiation ${ }^{b}$ & 45582 & 10 & 28.6 & $1.02 \mathrm{E}-08$ \\
\hline Regulation of lymphocyte differentiation ${ }^{b}$ & 45619 & 11 & 18.6 & $2.28 \mathrm{E}-07$ \\
\hline Positive regulation of lymphocyte differentiation ${ }^{b}$ & 45621 & 10 & 27.0 & $1.85 \mathrm{E}-08$ \\
\hline Regulation of lymphocyte proliferation ${ }^{b}$ & 50670 & 17 & 18.5 & $1.37 \mathrm{E}-10$ \\
\hline Positive regulation of lymphocyte proliferation ${ }^{b}$ & 50671 & 14 & 23.3 & $2.22 \mathrm{E}-10$ \\
\hline Positive regulation of inflammatory response $e^{b}$ & 50729 & 12 & 25.5 & $1.42 \mathrm{E}-09$ \\
\hline Positive regulation of immune response ${ }^{b}$ & 50778 & 19 & 12.8 & $7.76 \mathrm{E}-09$ \\
\hline Regulation of T-cell activation ${ }^{b}$ & 50863 & 16 & 14.3 & $2.30 \mathrm{E}-08$ \\
\hline
\end{tabular}




\begin{tabular}{llrr}
\hline G0 term & G0 ID & $n$ & \\
\hline Positive regulation of T-cell activation $^{b}$ & 50870 & 14 & \\
Positive regulation of B-cell activation $^{b}$ & 50871 & 14 & 19.7 \\
Leukocyte migration $^{b}$ & 50900 & 12 & $2.39 \mathrm{E}-09$ \\
Regulation of lymphocyte activation $^{b}$ & 51249 & 25 & $2.03 \mathrm{E}-13$ \\
Positive regulation of lymphocyte activation $^{b}$ & 51251 & $1.84 \mathrm{E}-09$ \\
Positive regulation of leukocyte proliferation $^{b}$ & 70665 & $1.63 \mathrm{E}-13$ \\
\hline
\end{tabular}

A number of $\mathrm{G} 0$ terms are overrepresented in the WT AEW-treated mice relative to WT VEH-treated mice. G0 terms are listed with corresponding $p$-values.

aScratch-dependent only (genes that are not significant in "no scratch" AEW- versus VEH-treated mice).

${ }^{b}$ TRPA1 - and scratch-dependent (genes that are not significant in Trpa ${ }^{-1-}$ AEW- versus VEH-treated mice and no scratch AEW- versus VEH-treated mice).

TRPA1-dependent only (genes that are not significant in Trpa ${ }^{-1-}$ AEW- versus VEH-treated mice).

sponse to a previously non-itchy stimulus (e.g., a light brush of the skin that is normally perceived as innocuous touch induces an intense desire to scratch) (Ikoma et al., 2004; Hong et al., 2011). The changes in sensitivity are hypothesized to occur as a result of increased innervation of itch-sensitive primary afferent fibers and expressional changes that drive hyperexcitabilty in sensory neurons (Ikoma et al., 2006; Tominaga et al., 2007; Kamo et al., 2011; Tominaga et al., 2011; Ständer et al., 2011). Whereas extensive transcriptome profiling of pruritic skin has been performed, much less is known about the changes within the sensory neurons that innervate this skin. We show here for the first time that AEW-evoked drying of the cheek skin leads to significant expressional changes in the sensory neurons of the TG. Although we cannot distinguish whether these changes are scratch dependent or independent, they are nevertheless a consequence of the normal itch-scratch cycle associated with chronic itch. Therefore, these genes represent novel candidate transducers of chronic itch. One such candidate is the bradykinin receptor 2. Injection of bradykinin evokes weak itch and pain sensations in healthy subjects, whereas bradykinin injection in patients with chronic itch triggers severe itch that is not relieved by antihistamine treatment (Hosogi et al., 2006). Therefore, increased expression of the bradykinin receptor in sensory neurons during chronic itch may result in alloknesis. In general, this analysis now provides a list of novel genes that represent candidate neuron-specific factors that might play a role in the pathophysiology of itch conditions. Future studies will be required to test the roles of such candidates in chronic itch models.

The ion channel TRPA1 was previously shown to mediate acute histamine-independent itch: TRPA1 is required for sensory neuron activation and itch behavior downstream of two histamine-independent pruritogens, chloroquine and BAM8-22, which activate MrgprA3 and MrgprC11, respectively (Liu et al., 2009; Wilson et al., 2011). Likewise, a MrgprA3-positive subset of neurons that express TRPA1 were recently shown to be required for acute and chronic itch (Han et al., 2013). Our data now demonstrate a new role for TRPA1 ion channels in multiple facets of chronic itch. We found that functional TRPA1 is required for all of the dry-skin-evoked phenotypes documented here, including AEW-evoked scratching, hyperplasia, and expressional changes in the skin. One striking result is that TRPA1 promotes dramatic changes in gene expression in the skin. Seventy-nine percent of the itch-related genes upregulated in the cheek model are TRPA1-dependent, $11 \%$ of which are independent of scratching. Among the human disease genes modulated in the cheek model, TRPA1 regulates both scratch-dependent and scratchindependent changes: AQP3, IL-33, Cxcr2, lipocalin, Slc9a3r1, and S100a9 require TRPA1 and are independent of the itchscratch cycle, whereas $\mathrm{Ccl} 27$ and Tnc are scratch and TRPA1 dependent. These genes play diverse roles in the initiation and maintenance of chronic itch. For example, AQP3, the predominant aquaporin in human skin, is upregulated in atopic dermatitis (Olsson et al., 2006) and mice lacking AQP3 display reduced hyperplasia in mouse models of atopic dermatitis (Nakahigashi et al., 2011). Our findings that AQP3 expression is TRPA1 dependent in the absence of scratching support a model for sensory neurons signaling to keratinocytes under chronic itch conditions. Another TRPA1-dependent gene, IL-33, displays enhanced expression in psoriatic skin and may act in concert with substance $\mathrm{P}$ to increase VEGF expression and release in psoriatic skin (Theoharides et al., 2010). This also supports an active role for neuronal signaling in the periphery in the development of chronic itch.

It is quite striking that TRPA1 channels mediate expressional changes of so many chronic itch genes. Key next steps in characterizing the role of TRPA1 will include identifying the endogenous upstream factors that activate TRPA1 during chronic itch and determining whether hyperplasia is caused by a TRPA1dependent release of inflammatory agents. Peptide release promotes vasodilation, vascular leakage, recruitment of immune cells, and, notably, epidermal hyperplasia in chronic itch through modulation of keratinocyte growth (Basbaum et al., 2009; Roggenkamp et al., 2013). Indeed, a role for neurogenic inflammation has been suggested in PAR2-mediated itch behavior in mice (Costa et al., 2008). Consistent with this model, we show here that genes involved in the regulation of leukocyte activation and chemotaxis are upregulated in AEW-treated mice in a TRPA1-dependent fashion (Table 1). It is also possible that TRPA1 expression in keratinocytes contributes to the AEW phenotype, although non-neuronal expression of TRPA1 is controversial (Story et al., 2003; Bautista et al., 2005; Kobayashi et al., 2005; Nagata et al., 2005; Kwan et al., 2009). Future studies using tissue-specific TRPA1-deficient animals are required to resolve whether TRPA1 in neurons or non-neuronal cells is necessary for AEW-evoked dry skin. Nonetheless, we show here for the first time a role for TRPA1 in epidermal homeostasis under a disease state, provide new insight into the role of TRPA1 in chronic itch, and highlight the potential benefit of TRPA1 antagonists as therapies for pathological itch conditions.

\section{References}

Akiyama T, Tominaga M, Carstens MI, Carstens EE (2012) Site-dependent and state-dependent inhibition of pruritogen-responsive spinal neurons by scratching. Eur J Neurosci 36:2311-2316. CrossRef Medline

Andoh T, Nagasawa T, Satoh M, Kuraishi Y (1998) Substance P induction of itch-associated response mediated by cutaneous NK1 tachykinin receptors in mice. J Pharmacol Exp Ther 286:1140-1145. Medline

Bánvölgyi A, Pozsgai G, Brain SD, Helyes ZS, Szolcsányi J, Ghosh M, Melegh B, Pintér E (2004) Mustard oil induces a transient receptor potential vanilloid 1 receptor-independent neurogenic inflammation and a nonneurogenic cellular inflammatory component in mice. Neuroscience 125 : 449-459. CrossRef Medline 
Basbaum AI, Bautista DM, Scherrer G, Julius D (2009) Cellular and molecular mechanisms of pain. Cell 139:267-284. CrossRef Medline

Bautista DM, Movahed P, Hinman A, Axelsson HE, Sterner O, Högestätt ED, Julius D, Jordt SE, Zygmunt PM (2005) Pungent products from garlic activate the sensory ion channel TRPA1. Proc Natl Acad Sci U S A 102: 12248-12252. CrossRef Medline

Bautista DM, Jordt SE, Nikai T, Tsuruda PR, Read AJ, Poblete J, Yamoah EN, Basbaum AI, Julius D (2006) TRPA1 mediates the inflammatory actions of environmental irritants and proalgesic agents. Cell 124:1269-1282. CrossRef Medline

Bolstad BM, Irizarry RA, Astrand M, Speed TP (2003) A comparison of normalization methods for high density oligonucleotide array data based on variance and bias. Bioinformatics 19:185-193. CrossRef Medline

Bowcock AM, Cookson WO (2004) The genetics of psoriasis, psoriatic arthritis and atopic dermatitis. Hum Mol Genet 13:R43-R55. CrossRef Medline

Costa R, Marotta DM, Manjavachi MN, Fernandes ES, Lima-Garcia JF, Paszcuk AF, Quintão NL, Juliano L, Brain SD, Calixto JB (2008) Evidence for the role of neurogenic inflammation components in trypsinelicited scratching behaviour in mice. Br J Pharmacol 154:1094-1103. CrossRef Medline

Dai Y, Wang S, Tominaga M, Yamamoto S, Fukuoka T, Higashi T, Kobayashi K, Obata K, Yamanaka H, Noguchi K (2007) Sensitization of TRPAl by PAR2 contributes to the sensation of inflammatory pain. J Clin Invest 117:1979-1987. CrossRef Medline

Dong X, Han S, Zylka MJ, Simon MI, Anderson DJ (2001) A diverse family of GPCRs expressed in specific subsets of nociceptive sensory neurons. Cell 106:619-632. CrossRef Medline

Grastilleur S, Mouledous L, Bedel J, Etcheverry J, Bader M, Girolami JP, Fourcade O, Frances B, Minville V (2013) Role of kinin B2 receptors in opioid-induced hyperalgesia in inflammatory pain in mice. Biol Chem 394:361-368. CrossRef Medline

Han L, Ma C, Liu Q, Weng HJ, Cui Y, Tang Z, Kim Y, Nie H, Qu L, Patel KN, Li Z, McNeil B, He S, Guan Y, Xiao B, Lamotte RH, Dong X (2013) A subpopulation of nociceptors specifically linked to itch. Nat Neurosci 16:174-182. CrossRef Medline

Hashimoto Y, Arai I, Nakanishi Y, Sakurai T, Nakamura A, Nakaike S (2004) Scratching of their skin by NC/Nga mice leads to development of dermatitis. Life Sci 76:783-794. CrossRef Medline

Hashimoto Y, Takaoka A, Sugimoto M, Honma Y, Sakurai T, Futaki N, Arai I (2011) Itch-associated scratching contributes to the development of dermatitis and hyperimmunoglobulinaemia E in NC/Nga mice. Exp Dermatol 20:820-825. CrossRef Medline

Hon KL, Wong KY, Leung TF, Chow CM, Ng PC (2008) Comparison of skin hydration evaluation sites and correlations among skin hydration, transepidermal water loss, SCORAD index, Nottingham Eczema Severity Score, and quality of life in patients with atopic dermatitis. Am J Clin Dermatol 9:45-50. CrossRef Medline

Hong J, Buddenkotte J, Berger TG, Steinhoff M (2011) Management of itch in atopic dermatitis. Semin Cutan Med Surg 30:71-86. CrossRef Medline

Hosogi M, Schmelz M, Miyachi Y, Ikoma A (2006) Bradykinin is a potent pruritogen in atopic dermatitis: a switch from pain to itch. Pain 126:1623. CrossRef Medline

Ikoma A, Fartasch M, Heyer G, Miyachi Y, Handwerker H, Schmelz M (2004) Painful stimuli evoke itch in patients with chronic pruritus: central sensitization for itch. Neurology 62:212-217. CrossRef Medline

Ikoma A, Steinhoff M, Ständer S, Yosipovitch G, Schmelz M (2006) The neurobiology of itch. Nat Rev Neurosci 7:535-547. CrossRef Medline

Imamachi N, Park GH, Lee H, Anderson DJ, Simon MI, Basbaum AI, Han SK (2009) TRPV1-expressing primary afferents generate behavioral responses to pruritogens via multiple mechanisms. Proc Natl Acad Sci U S A 106:11330-11335. CrossRef Medline

Irizarry RA, Bolstad BM, Collin F, Cope LM, Hobbs B, Speed TP (2003a) Summaries of Affymetrix GeneChip probe level data. Nucleic Acids Res 31:e15. CrossRef Medline

Irizarry RA, Hobbs B, Collin F, Beazer-Barclay YD, Antonellis KJ, Scherf U, Speed TP (2003b) Exploration, normalization, and summaries of high density oligonucleotide array probe level data. Biostatistics 4:249-264. CrossRef Medline

Jeffry J, Kim S, Chen ZF (2011) Itch signaling in the nervous system. Physiology 26:286-292. CrossRef Medline

Jinks SL, Carstens E (2002) Responses of superficial dorsal horn neurons to intradermal serotonin and other irritants: comparison with scratching behavior. J Neurophysiol 87:1280-1289. Medline

Kamei J, Nagase H (2001) Norbinaltorphimine, a selective kappa-opioid receptor antagonist, induces an itch-associated response in mice. Eur J Pharmacol 418:141-145. CrossRef Medline

Kamo A, Tominaga M, Negi O, Tengara S, Ogawa H, Takamori K (2011) Topical application of emollients prevents dry skin-inducible intraepidermal nerve growth in acetone-treated mice. J Dermatol Sci 62:64-66. CrossRef Medline

Karai L, Brown DC, Mannes AJ, Connelly ST, Brown J, Gandal M, Wellisch OM, Neubert JK, Olah Z, Iadarola MJ (2004) Deletion of vanilloid receptor 1-expressing primary afferent neurons for pain control. J Clin Invest 113:1344-1352. CrossRef Medline

Kawasaki H, Kubo A, Sasaki T, Amagai M (2011) Loss-of-function mutations within the filaggrin gene and atopic dermatitis. Curr Probl Dermatol 41:35-46. CrossRef Medline

Kim DH, Ahn BO, Kim SH, Kim WB (1999) Antipruritic effect of DA-5018, a capsaicin derivative, in mice. Arch Pharm Res 22:549-553. CrossRef Medline

Kobayashi K, Fukuoka T, Obata K, Yamanaka H, Dai Y, Tokunaga A, Noguchi K (2005) Distinct expression of TRPM8, TRPA1, and TRPV1 mRNAs in rat primary afferent neurons with adelta/c-fibers and colocalization with trk receptors. J Comp Neurol 493:596-606. CrossRef Medline

Kuraishi Y, Nagasawa T, Hayashi K, Satoh M (1995) Scratching behavior induced by pruritogenic but not algesiogenic agents in mice. Eur J Pharmacol 275:229-233. CrossRef Medline

Kwan KY, Glazer JM, Corey DP, Rice FL, Stucky CL (2009) TRPA1 modulates mechanotransduction in cutaneous sensory neurons. J Neurosci 29: 4808-4819. CrossRef Medline

Lagerström MC, Rogoz K, Abrahamsen B, Persson E, Reinius B, Nordenankar K, Olund C, Smith C, Mendez JA, Chen ZF, Wood JN, Wallén-Mackenzie A, Kullander K (2010) VGLUT2-dependent sensory neurons in the TRPV1 population regulate pain and itch. Neuron 68:529-542. CrossRef Medline

Lee Y, Je YJ, Lee SS, Li ZJ, Choi DK, Kwon YB, Sohn KC, Im M, Seo YJ, Lee JH (2012) Changes in transepidermal water loss and skin hydration according to expression of aquaporin-3 in psoriasis. Ann Dermatol 24:168-174. CrossRef Medline

Liu Q, Tang Z, Surdenikova L, Kim S, Patel KN, Kim A, Ru F, Guan Y, Weng HJ, Geng Y, Undem BJ, Kollarik M, Chen ZF, Anderson DJ, Dong X (2009) Sensory neuron-specific GPCR Mrgprs are itch receptors mediating chloroquine-induced pruritus. Cell 139:1353-1365. CrossRef Medline

Liu XY, Liu ZC, Sun YG, Ross M, Kim S, Tsai FF, Li QF, Jeffry J, Kim JY, Loh HH, Chen ZF (2011) Unidirectional cross-activation of GRPR by MOR1D uncouples itch and analgesia induced by opioids. Cell 147:447458. CrossRef Medline

Ljosaa TM, Stubhaug A, Mork C, Moum T, Wahl AK (2012) Improvement in psoriasis area and severity index score predicts improvement in skin pain over time in patients with psoriasis. Acta dermato-venereologica.

Maekawa T, Yamaguchi-Miyamoto T, Nojima H, Kuraishi Y (2002) Effects of naltrexone on spontaneous itch-associated responses in NC mice with chronic dermatitis. Jpn J Pharmacol 90:193-196. CrossRef Medline

Matta JA, Cornett PM, Miyares RL, Abe K, Sahibzada N, Ahern GP (2008) General anesthetics activate a nociceptive ion channel to enhance pain and inflammation. Proc Natl Acad Sci U S A 105:8784-8789. CrossRef Medline

Mihara K, Kuratani K, Matsui T, Nakamura M, Yokota K (2004) Vital role of the itch-scratch response in development of spontaneous dermatitis in NC/Nga mice. Br J Dermatol 151:335-345. CrossRef Medline

Mishra SK, Hoon MA (2010) Ablation of TrpV1 neurons reveals their selective role in thermal pain sensation. Mol Cell Neurosci 43:157-163. CrossRef Medline

Mishra SK, Tisel SM, Orestes P, Bhangoo SK, Hoon MA (2011) TRPV1lineage neurons are required for thermal sensation. EMBO J 30:582-593. CrossRef Medline

Mitchell K, Bates BD, Keller JM, Lopez M, Scholl L, Navarro J, Madian N, Haspel G, Nemenov MI, Iadarola MJ (2010) Ablation of rat TRPV1expressing Adelta/C-fibers with resiniferatoxin: analysis of withdrawal behaviors, recovery of function and molecular correlates. Mol Pain 6:94. CrossRef Medline 
Miyamoto T, Nojima H, Kuraishi Y (2002a) Intradermal cholinergic agonists induce itch-associated response via M3 muscarinic acetylcholine receptors in mice. Jpn J Pharmacol 88:351-354. CrossRef Medline

Miyamoto T, Nojima H, Shinkado T, Nakahashi T, Kuraishi Y (2002b) Itchassociated response induced by experimental dry skin in mice. Jpn J Pharmacol 88:285-292. CrossRef Medline

Nagata K, Duggan A, Kumar G, García-Añoveros J (2005) Nociceptor and hair cell transducer properties of TRPA1, a channel for pain and hearing. J Neurosci 25:4052-4061. CrossRef Medline

Nakahigashi K, Kabashima K, Ikoma A, Verkman AS, Miyachi Y, HaraChikuma M (2011) Upregulation of aquaporin-3 is involved in keratinocyte proliferation and epidermal hyperplasia. J Invest Dermatol 131: 865-873. CrossRef Medline

Nakano T, Andoh T, Sasaki A, Nojima H, Kuraishi Y (2008) Different roles of capsaicin-sensitive and $\mathrm{H} 1$ histamine receptor-expressing sensory neurones in itch of mosquito allergy in mice. Acta dermato-venereologica 88:449-454. CrossRef Medline

Nojima H, Carstens MI, Carstens E (2003) c-fos expression in superficial dorsal horn of cervical spinal cord associated with spontaneous scratching in rats with dry skin. Neurosci Lett 347:62-64. CrossRef Medline

Olsson M, Broberg A, Jernås M, Carlsson L, Rudemo M, Suurküla M, Svensson PA, Benson M (2006) Increased expression of aquaporin 3 in atopic eczema. Allergy 61:1132-1137. CrossRef Medline

Orito K, Chida Y, Fujisawa C, Arkwright PD, Matsuda H (2004) A new analytical system for quantification scratching behaviour in mice. $\mathrm{Br} \mathrm{J}$ Dermatol 150:33-38. CrossRef Medline

Roggenkamp D, Kopnick S, Stab F, Wenck H, Schmelz M, Neufang G (2013) Epidermal nerve fibers modulate keratinocyte growth via neuropeptide signaling in an innervated skin model. J Invest Dermatol.

Rojavin MA, Cowan A, Radzievsky AA, Ziskin MC (1998) Antipruritic effect of millimeter waves in mice: evidence for opioid involvement. Life Sci 63:PL251-257. CrossRef Medline

Ross SE, Mardinly AR, McCord AE, Zurawski J, Cohen S, Jung C, Hu L, Mok SI, Shah A, Savner EM, Tolias C, Corfas R, Chen S, Inquimbert P, Xu Y, McInnes RR, Rice FL, Corfas G, Ma Q, Woolf CJ, Greenberg ME (2010) Loss of inhibitory interneurons in the dorsal spinal cord and elevated itch in Bhlhb5 mutant mice. Neuron 65:886-898. CrossRef Medline

Rotty JD, Coulombe PA (2012) A wound-induced keratin inhibits Src activity during keratinocyte migration and tissue repair. J Cell Biol 197:381389. CrossRef Medline

Russell FA, Veldhoen VE, Tchitchkan D, McDougall JJ (2010) Proteinaseactivated receptor-4 (PAR4) activation leads to sensitization of rat joint primary afferents via a bradykinin B2 receptor-dependent mechanism. J Neurophysiol 103:155-163. CrossRef Medline

Shimada SG, LaMotte RH (2008) Behavioral differentiation between itch and pain in mouse. Pain 139:681-687. CrossRef Medline

Shimada SG, Shimada KA, Collins JG (2006) Scratching behavior in mice induced by the proteinase-activated receptor-2 agonist, SLIGRL-NH2. Eur J Pharmacol 530:281-283. CrossRef Medline

Sonkoly E, Muller A, Lauerma AI, Pivarcsi A, Soto H, Kemeny L, Alenius H, Dieu-Nosjean MC, Meller S, Rieker J, Steinhoff M, Hoffmann TK, Ruzicka T, Zlotnik A, Homey B (2006) IL-31: a new link between T cells and pruritus in atopic skin inflammation. J Allergy Clin Immunol 117:411-417. CrossRef Medline

Ständer S, Raap U, Weisshaar E, Schmelz M, Mettang T, Handwerker H, Luger TA (2011) Pathogenesis of pruritus. J Dtsch Dermatol Ges 9:456-463. CrossRef Medline

Stefansson K, Brattsand M, Roosterman D, Kempkes C, Bocheva G, Steinhoff M, Egelrud T (2008) Activation of proteinase-activated receptor-2 by human kallikrein-related peptidases. J Invest Dermatol 128:18-25. CrossRef Medline
Story GM, Peier AM, Reeve AJ, Eid SR, Mosbacher J, Hricik TR, Earley TJ, Hergarden AC, Andersson DA, Hwang SW, McIntyre P, Jegla T, Bevan S, Patapoutian A (2003) ANKTM1, a TRP-like channel expressed in nociceptive neurons, is activated by cold temperatures. Cell 112:819-829. CrossRef Medline

Sugimoto M, Arai I, Futaki N, Honma Y, Sakurai T, Hashimoto Y, Nakaike S (2007) Putative mechanism of the itch-scratch circle: repeated scratching decreases the cutaneous level of prostaglandin D2, a mediator that inhibits itching. Prostaglandins Leukot Essent Fatty Acids 76:93-101. CrossRef Medline

Sun YG, Chen ZF (2007) A gastrin-releasing peptide receptor mediates the itch sensation in the spinal cord. Nature 448:700-703. CrossRef Medline

Sun YG, Zhao ZQ, Meng XL, Yin J, Liu XY, Chen ZF (2009) Cellular basis of itch sensation. Science 325:1531-1534. CrossRef Medline

Suwa E, Yamaura K, Oda M, Namiki T, Ueno K (2011) Histamine H(4) receptor antagonist reduces dermal inflammation and pruritus in a hapten-induced experimental model. Eur J Pharmacol 667:383-388. CrossRef Medline

Takaoka A, Arai I, Sugimoto M, Futaki N, Sakurai T, Honma Y, Nakaike S (2007) Role of scratch-induced cutaneous prostaglandin D production on atopic-like scratching behaviour in mice. Exp Dermatol 16:331-339. CrossRef Medline

Theoharides TC, Zhang B, Kempuraj D, Tagen M, Vasiadi M, Angelidou A, Alysandratos KD, Kalogeromitros D, Asadi S, Stavrianeas N, Peterson E, Leeman S, Conti P (2010) IL-33 augments substance P-induced VEGF secretion from human mast cells and is increased in psoriatic skin. Proc Natl Acad Sci U S A 107:4448-4453. CrossRef Medline

Thomsen JS, Simonsen L, Benfeldt E, Jensen SB, Serup J (2002) The effect of topically applied salicylic compounds on serotonin-induced scratching behaviour in hairless rats. Exp Dermatol 11:370-375. CrossRef Medline

Tominaga M, Ozawa S, Tengara S, Ogawa H, Takamori K (2007) Intraepidermal nerve fibers increase in dry skin of acetone-treated mice. J Dermatol Sci 48:103-111. CrossRef Medline

Tominaga M, Tengara S, Kamo A, Ogawa H, Takamori K (2011) Matrix metalloproteinase- 8 is involved in dermal nerve growth: implications for possible application to pruritus from in vitro models. J Invest Dermatol 131:2105-2112. CrossRef Medline

von Banchet GS, Petrow PK, Bräuer R, Schaible HG (2000) Monoarticular antigen-induced arthritis leads to pronounced bilateral upregulation of the expression of neurokinin 1 and bradykinin 2 receptors in dorsal root ganglion neurons of rats. Arthritis Res 2:424-427. CrossRef Medline

Wilson SR, Gerhold KA, Bifolck-Fisher A, Liu Q, Patel KN, Dong X, Bautista DM (2011) TRPA1 is required for histamine-independent, Mas-related G protein-coupled receptor-mediated itch. Nat Neurosci 14:595-602. CrossRef Medline

Yamamoto M, Haruna T, Ueda C, Asano Y, Takahashi H, Iduhara M, Takaki S, Yasui K, Matsuo Y, Arimura A (2009) Contribution of itch-associated scratch behavior to the development of skin lesions in Dermatophagoides farinae-induced dermatitis model in NC/Nga mice. Arch Dermatol Res 301:739-746. CrossRef Medline

Yamaoka J, Di ZH, Sun W, Kawana S (2007) Changes in cutaneous sensory nerve fibers induced by skin-scratching in mice. J Dermatol Sci 46:41-51. CrossRef Medline

Yamaura K, Oda M, Suwa E, Suzuki M, Sato H, Ueno K (2009) Expression of histamine $\mathrm{H} 4$ receptor in human epidermal tissues and attenuation of experimental pruritus using $\mathrm{H} 4$ receptor antagonist. J Toxicol Sci 34:427-431. CrossRef Medline

Yosipovitch G (2004) Dry skin and impairment of barrier function associated with itch-new insights. Int J Cosmetic Sci 26:1-7. CrossRef Medline

Yosipovitch G, Samuel LS (2008) Neuropathic and psychogenic itch. Dermatol Ther 21:32-41. CrossRef Medline 